He was seen by Professor Paterson Ross, of St. Bartholomew's Hospital, who advised a linear osteotomy of the skull bones to relieve pain. This was done on August 22, 1938. The bone over the left parietal area was found to be between one and a half to two inches thick and very soft, but with no cysts. A longitudinal strip of bone half an inch wide was removed, and was followed by a marked improvement in the general condition of the patient, who was now free from headaches for the first time for a year. However, two months later he knocked his head, and following this his pains began again. When last seen some weeks ago, there was still no sign of involvement of the optic nerve, but the swelling of the head had increased, and the headaches were returning, though not so severely as before. It would seem to be only a matter of time before the left optic nerve becomes atrophic.

Report on bone remored. The sections show compact bone in which the Haversian canals are enlarged and contain somewhat vascular fibrous tissue which is almost acellular. There is no evidence of lacunar resorption of bone, and no new bone is being laid down. The appearance of the bone is consistent with that found in osteitis fibrosa.

\title{
BIBLIOGRAPHY
}

CaPon.-Archiv. Dis. Child., Vol III, p. 285, 1928.

Chambers.-Proc. Roy. Soc. Med., Vol. XXIII, Part 2, p. 1006, 1930.

Greene.-Amer. Jl Ophthal., Vol. XXXII, p. 293, 1915.

Harman.-Proc. Roy. Soc. Med., Sect. Ophthal., Vol. XIV, p. 11, 1921.

Howship.-Observations in Surgery, 1819.

KNAGgs.-Brit. Jl. of Surgery, Vol. II, p. 347, 1923.

MORELli.-Annal. ai Ottal., Vol. LIII, pp. 773-787, 1925.

STACK.-Quoted by Harman.

VIRchow.-Pathologie des Tumeurs, Vol. XXI, 1896.

von PAAs.-Zeitschr. $f$. Augenheilk., Vol. XCII, pp. 221-230, 1937.

\section{CULTURE IN VITRO OF THE CORPUSCLES OF TRACHOMA}

\author{
BY \\ DR. L. POLEFF \\ INSTITUT D'HYGIENE DU MAROC
}

IN his comprehensive report on the aetiology of trachoma MacCallan concludes that the causal agent of this infection is certainly a virus. The group of minute organisms to which it belongs is characterized by the following features: (1) The formation of intracellular inclusions in the tissues affected by the 


\section{EXPLANATION OF FIGURES}

ORIGIN : Cellular culture of trachomatous conjunctiva (series 23) in which the films showed only very few Rickettsia-like bodies (elementary bodies), and absence of inclusions.

Incubation: 10 days. Staining with Castaneda-Lepine. Magnification $\times 1000$

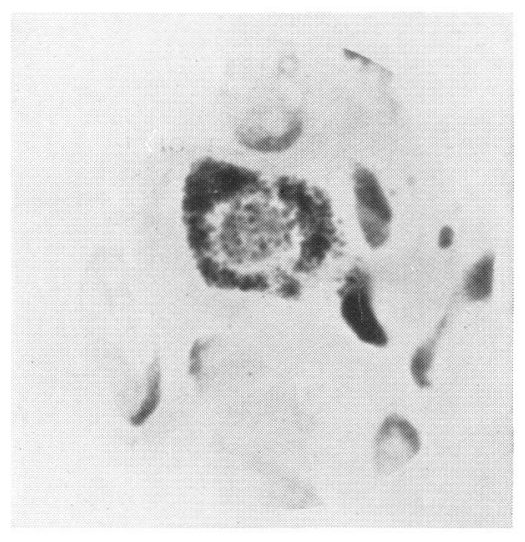

FIG. 1.

Epithelial cell crammed with elementary bodies. Classical appearance.

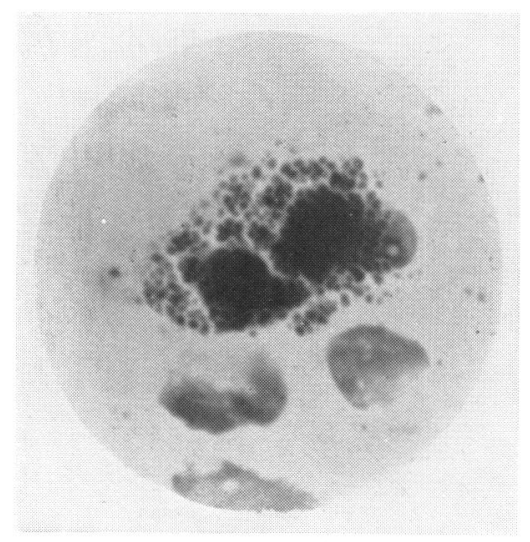

FIG. 2.

Voluminous inclusions consisting of initial bodies in process of division. 


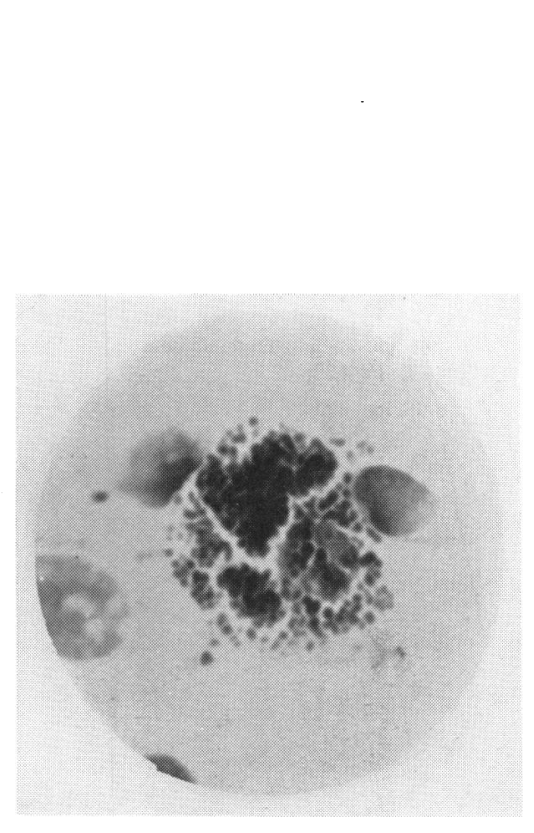

FIG. 3.

Epithelial cell which has just burst full of mulberrylike inclusions.

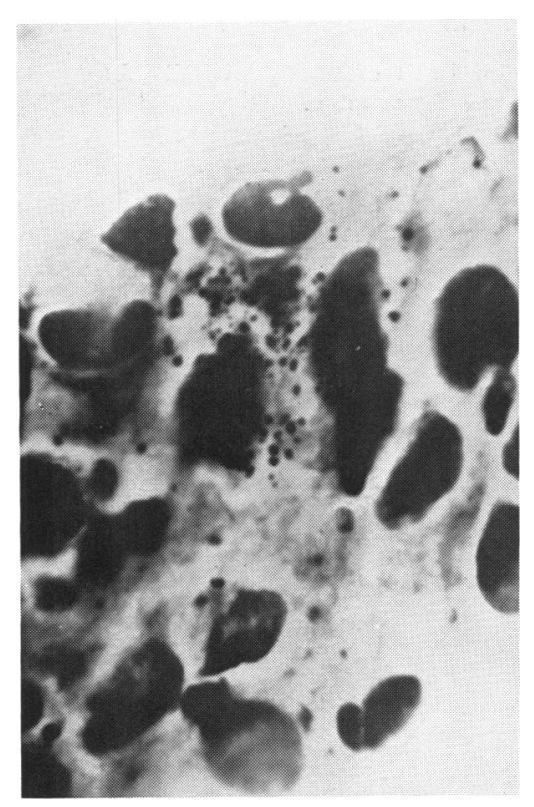

FIG. 4.

Free initial and elementary bodies.

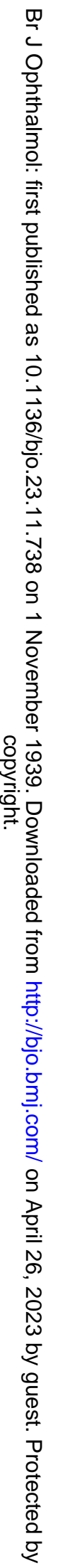




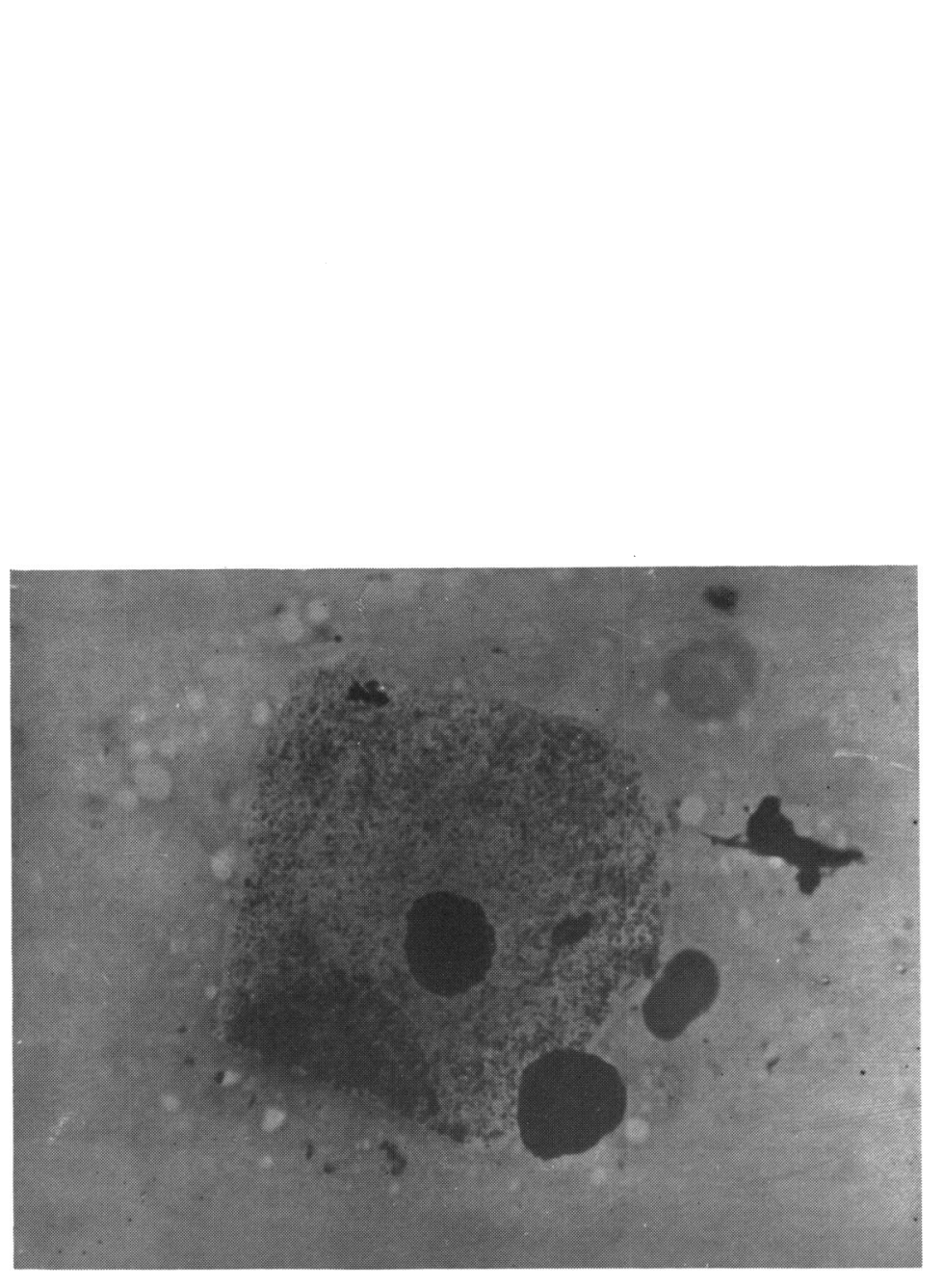

FIG. 5.

Elementary bodies in an epithelial cell from a trachomatous conjunctiva. 
NOTE BY TRANSLATOR

Dr. Poleff published his first account of the tissue-culture of trachoma in 1936 (Arch. d'Ophtal., p. 882). He has found the best culture media to be the human placenta and the human corneal tissue. The microphotographs which illustrate his paper are what he believes to be the aetiological agent of trachoma in several phases of development obtained from tissue cultures. For purposes of comparison a microphotograph of a human epithelial cell from the conjunctiva of a trachomatous person is included, showing elementary bodies: magnification $\times 2000$; taken at Westminster Hospital Research Laboratories. 
pathological process and which present a certain stage in the evolution of the causative agent. (2) Filterability of the primitive elements (elementary bodies) of the virus through porcelain filters, through which ordinary bacteria cannot pass. (3) Obligatory parasitism, that is to say development in vitro occurs only in the presence of living cells.

The intracellular inclusions of trachoma were discovered in 1907 by Halberstaedter and Prowaczek, as everyone knows. Already before the world war Axenfeld in his classical work on the aetiology of trachoma asserted their importance, and this has been emphasized more recently by Thygeson and his co-workers, by Julianelle and Harrison, as well as more particularly by the recent work of Foley and Parrot (Arch. Inst. Pasteur d'Algerie, Vols. $\mathrm{XV}, \mathrm{XVI}$ ).

The filterability of trachoma virus was established by Nicolle, Cuénod and Blaizot in 1912, and has recently been confirmed by Thygeson.

I have shown the relationship which exists between the smallest forms of the virus (elementary bodies) and the intracellular inclusions by cellular cultures of trachoma; this was carried out on more than ten thousand films and sections prepared from these cultures, and from these, studies have been made as to the stages of development, and their living nature has been proved. Proof of vitality, which can only be obtained on appropriate living tissue, is an important if not decisive argument in favour of the aetiological specificity of inclusions and their derivatives in trachoma.

In view of the uncertainty which exists as to the culture of the trachomatous corpuscles I present to this Meeting of the International Organization against Trachoma a series of microphotographs which exhibit typical pictures of the various stages of their evolution in vitro. In the original preparations, of which these are photographs, the corpuscles appear in such a fashion that I can now have no doubt as to their parasitic nature. According to their cycle of evolution observed in vitro, which corresponds in general with the results obtained by myself and many others on fresh trachomatous tissue, these parasitic atoms probably belong to the class of ultraviruses, but their exact biomorphological classification, virus or Rickettsia, seems to be uncertain. In German and English literature they are described as elementary bodies (virus-forming inclusions). Busacca was the first to suggest that the virus of trachoma belonged to the Rickettsiae and had nothing to do with the epithelial inclusions of Halberstaedter and Prowaczek.

However this conception of Busacca is accepted by no one. My 
own observations have always led me to conclude that the Rickettsia-like corpuscles described by Busacca, and later by Cuénod, at any rate those which are not debris, cellular and other, are identical with the inclusion of Halberstaedter and Prowaczek at certain stages of their evolution.

At the present time most trachomatologists believe that we are concerned with a single minute infecting agent, which has characters both of a virus and of a Rickettsia. The culture of this element in vitro and the inoculation of susceptible animals, and man also, may allow a precise definition to be made.

\section{ANNOTATION}

\section{November 1st, $1914: 1939$}

Five and twenty years ago to the day the Germans were responsible for a piece of atrocity of a particularly uncivilised nature. We refer to the deliberate murder of Angus McNab while engaged in giving first-aid to wounded London Scottish after the charge at Messines.

It was bright moonlight at the time; McNab, himself wounded, was unarmed and wearing the Red-cross badge. In short it was entirely unjustified.

McNab spoke German fluently, had worked in Axenfeld's clinic at Freiburg and was a great admirer of German clinical and labora. tory methods. It was one of the ironies of fate that he should have lost his life thus at the hands of the nation he so much admired.

Twenty-five years later the British Empire is again at war with Germany, and even in these early days of the war the same uncivilised methods are again in evidence.

\section{ABSTRACTS}

\section{I.-RETINA}

(1) Kurz, Otto (Prague).- The clinical features and pathogenesis of non-myopic detachments of the retina. ( $Z$ ur Klinik und Pathogenese der nichtmyopischen Netzhautabhebungenstarre Abhebung, Netzhautcysten, Netzhautspaltung). Arch. f. Ophthàl., Vol. CXXXIX, p. 326.

(1) Kurz here deals with forms of detachment in which retinal tears do not form the most prominent feature-rigid detachments, retinal cysts and splitting of the retina. 